\title{
KEPUASAN PEMBELAJARAN SECARA ONLINE: APAKAH GAYA BELAJAR MEMPUNYAI PENGARUH?
}

\author{
M. Nur Ghufron \\ IAIN Kudus, Indonesia \\ emnurghufron78@iainkudus.ac.id
}

\begin{abstract}
Abstrak
Penelitian ini bertujuan menguji pengaruh gaya belajar tergantung dan gaya belajar bebas mahasiswa terhadap kepuasan pembelajaran secara online. Penelitian secara kuantitatif ini melibatkan 69 mahasiswa yang melaksanakan pembelajaran secara online. Teknik pengumpulan data yang digunakan dalam penelitian ini adalah kuesioner dalam bentuk skala. Ada tiga jenis skala yang digunakan dalam proses pengumpulan data, yaitu skala kepuasan pembelajaran secara online, gaya belajar tergantung dan gaya belajar bebas. Tehnik analisis data dengan menggunakan tehnik analisis regresi. Hasil penelitian menunjukkan bahwa, gaya belajar bebas berpengaruh secara positif terhadap kepuasan pembelajaran secara online sebesar 0.446, $\mathrm{p}=0.000$. Sementara gaya belajar tergantung berpengaruh secara negatif terhadap kepuasan pembelajarn secara online sebesar $-0.647, p=0.000$. Koefesien determinasi kepuasan pembelajaran secara online sebesar $\left(\mathrm{R}^{2}\right)=0.496$, yang bermakna bahwa 49 persen kepuasan pembelajaran secara online dapat dijelaskan atau diprediksi melalui variabel gaya belajar, baik gaya belajar bebas maupun gaya belajar tergantung.
\end{abstract}

Kata kunci : Gaya belajar tergantung, gaya belajar bebas dan kepuasan pembelajaran secara online.

\begin{abstract}
This study aims to examine the effect of field-dependent learning styles and field independent learning styles of students on online learning satisfaction. This quantitative research involved 69 students who conducted online learning. Data collection techniques used in this study were questionnaires in the form of scales. There are three types of scales used in the data collection process, namely online learning satisfaction scales, field-dependent learning styles and field independent learning styles. Data analysis techniques using regression analysis techniques. The results showed that field independent learning style had a positive effect on online learning satisfaction by 0.446 , $p=0.000$. While field-dependent learning style negatively affected online learning satisfaction of -0,647, $p=0,000$. The coefficient of determination of online learning satisfaction is $\left(R^{2}\right)=0.496$, which means that 49 percent of online learning satisfaction can be explained or predicted through learning style variables, both field independent learning styles and field-dependent learning styles.
\end{abstract}

Key Words: Field-dependent learning style, field independent learning style and online learning satisfaction. 


\section{A. Pendahuluan}

Sekarang ini dunia telah berada di era revolusi industri 4.0. Revolusi industri 4.0 merupakan tahapan perkembangan kemajuan dalam berbagai bidang yang yang didapatkan manusia dari waktu ke waktu. Di awali revolusi industri pertama, di mana air dan uap digunakan untuk memekanisasi produksi. Berikutnya revolusi industri ke-2, di mana tenaga listrik digunakan untuk membuat produksi secara massal. Selanjutnya revolusi industri ke-3, yang menjadikan elektronik dan teknologi informasi digunakan untuk mengotomatisasi produksi. Adapun pada era revolusi industri ke-4 sudah melewati peningkatan dari revolusi industri ke-3, di mana kemajuan teknologi baru mengaburkan batas antara fisik, dunia digital dan biologis. Teknologi baru berkembang dengan kecepatan eksponensial dan tidak ada preseden historis yang menandai awal evolusi, karenanya disebut juga era disrupsi teknologi. Kemajuan ini didorong oleh munculnya kecerdasan artifisial, robotika, internet, kendaraan otonom, bio dan nanoteknologi, pencetakan 3-D, ilmu material, komputasi kuantum dan penyimpanan energi (Diwan, 2017).

Revolusi industri 4.0 mempengaruhi tidak hanya bisnis, melainkan berpengaruh dalam bidang pemerintahan, masyarakat, juga mempengaruhi pendidikan. Pendidikan 4.0 adalah respons terhadap kebutuhan revolusi industri 4.0 di mana manusia dan teknologi diselaraskan untuk memungkinkan-kemungkinan baru, termasuk penggunaan Teknologi Informasi dan Komunikasi (TIK). Kemajuan di bidang Teknologi Informasi dan Komunikasi (TIK) yang sangat pesat telah menimbulkan dampak yang sangat besar dalam kehidupan manusia.

Teknologi informasi dan komunikasi (TIK) yang meliputi radio dan televisi, serta teknologi digital yang lebih baru seperti komputer dan internet telah disebut-sebut sebagai alat yang berpotensi kuat untuk perubahan dan pembaharuan pendidikan. Ketika TIK digunakan dengan tepat, maka dapat membantu memperluas akses pendidikan, memperkuat relevansi pendidikan dengan tempat kerja, dan meningkatkan kualitas pendidikan yang diantaranya membantu membuat pengajaran dan pembelajaran menjadi sebuah proses aktif dan menarik yang terhubung dengan kehidupan nyata.

Berbagai perubahan dalam kehidupan manusia juga merubah pola hidup dan perilaku manusia seperti perubahan dari era industri ke era informasi. Ada pernyataan bahwa "TIK mendekatkan yang jauh dan menjauhkan yang dekat". Dengan 
memanfaatkan gadget, komputer, laptop, netbook dan perangkat TIK lainnya, manusia dapat berkomunikasi dan berbagi informasi dengan orang lain di tempat yang jauh, namun komunikasi berupa basa-basi di tempat umum atau bahkan di rumah tangga sekalipun menjadi berkurang. Tidak jarang terjadi orang-orang berkumpul namun masing-masing asyik dengan gadgetnya.

Pembelajaran secara online juga merupakan salah satu bentuk perubahan yang terjadi dalam proses pembelajaran. Pembelajaran secara online menjadi arus utama di samping penyebaran secara cepat teknologi komputer dan peningkatan infrastruktur internet (Allen \& Seaman, 2008).

Penelitian sebelumnya tentang pembelajaran secara online berkonsentrasi faktorfaktor yang mempengaruhi kesuksesan dan kegagalan pembelajaran secara online (seperti, Bolliger \& Halupa, 2018; Shelton, Hung \& Lowenthal, 2017; Yang, Baldwin, \& Snelson, 2017) perbandingan hasil belajar antara pembelajaran secara online dan pembelajaran kelas tradisional, dan sebagian besar studi tidak menemukan perbedaan yang signifikan dalam hasil belajar (Allen, Bourhis, Burrell, \& Mabry, 2002; Biner, Bink, Huffman, \& Dean, 1997; Johnson, Aragon, Shaik, \& Palma-Rivas, 2000). Kepuasan ditekankan menjadi salah satu faktor terpenting yang menentukan kualitas pengajaran online. Bahwa keberhasilan kursus, program, dan proses pembelajaran dapat dinilai dengan kepuasan peserta didik (Phipps \& Merisotis, 1999). Kepuasan pembelajaran secara online sangat penting bagi universitas, karena telah dikaitkan dengan prestasi belajar (Battalio, 2007).

Kepuasan peserta didik dapat didefinisikan sebagai persepsi peserta didik tentang nilai pengalaman pendidikan dalam lingkungan pendidikan (Astin, 1993). Kepuasan pembelajaran secara online mahasiswa merupakan cerminan bagaimana mahasiswa mengalami dan memahami pembelajaran tersebut dan merupakan ukuran penting dalam evaluasi program suatu pembelajaran. Kepuasan adalah masalah yang sangat signifikan dalam pelaksanaan proses pembelajaran secara online yang merupakan ukuran kualitas dan efektivitas pengajaran dan pembelajaran (Bolliger \& Halupa, 2012). Kepuasan peserta didik adalah konsep penting karena pada akhirnya dapat menyebabkan tingkat motivasi yang lebih tinggi. Peserta didik tersebut lebih gigih dalam pembelajaran, dan bukti penelitian menunjukkan bahwa pembelajaran secara 
online memberikan pengalaman yang memuaskan, keterlibatan, pembelajaran, kinerja, dan kesuksesan (Sahin \& Shelley, 2008; Wickersham \& McGee, 2008).

Peserta didik yang mempunyai kepuasan pembelajaran secara online berkontribusi terhadap prestasi akademik. Semakin banyak mahasiswa yang mendapatkan kepuasan dalam pembelajaran secara online, maka lebih dapat melakukannya dengan baik di kehidupan nyata (Keller, 1983; Pike, 1993). Sebaliknya, ketidakpuasan dengan pembelajaran secara online dapat menjadikan mahasiswa tidak mempunyai semangat mengikuti pembelajaran, tidak puas dengan layanan perkuliahan atau pembelajaran yang dilakukan oleh lembaga atau institusi (McGivney, 2004). Penelitian mengenai kepuasan mahasiswa secara online dapat membantu para pendidik dan pengembang pendidikan secara online dalam meningkatkan efektivitas pembelajaran (Kelsey, Lindner, \& Dooley, 2002). Selain itu, kepuasan belajar peserta didik dapat digunakan sebagai referensi untuk perancang kurikulum pembelajaran secara online, juga dapat membantu para guru untuk memiliki pemahaman yang lebih baik tentang situasi belajar mengajar.

Penelitian sebelumnya menyelidiki faktor-faktor penting yang mempengaruhi kepuasan dalam lingkungan belajar online (misalnya, Artino, 2007; Bolliger \& Martindale, 2004; Reinhart \& Schneider, 2001; Sahin, 2007; Dziuban et al., 2018; Weidlich \& Bastiaens, 2018). Faktor-faktor yang dapat memprediksi kepuasan dalam pembelajaran online seperti kehadiran sosial, interaksi sosial, dan pembelajaran kolaboratif. Selain itu, kualitas teknologi, jarak fisik, komunikasi, ketersediaan teknologi, dan interaksi dengan pengajar dan teman, dan desain pembelajaran dapat berpengaruh terhadap kepuasan dalam pembelajaran online. Kepuasan dalam suatu pembelajaran adalah "bagian hasil" yang sangat penting (Astin, 1993).

Menurut Sahin dan Shelley (2008), faktor yang terkait dengan kepuasan peserta didik dalam pembelajaran jarak jauh adalah fleksibilitas, keahlian komputer, dan kegunaannya, perilaku instruktur, teknologi andal, dan komunikasi yang interaktif mempengaruhi kepuasan peserta didik (Bolliger \& Martindale, 2004; Dennen, Darabi, \& Smith, 2007). Persepsi individu tentang nilai tugas dan efikasi diri, kemampuan sosial, masalah desain instruksional, dan kualitas sistem pengiriman dan multimedia instruksi juga merupakan elemen penting (Liaw, 2008). Selain itu, karakteristik peserta 
didik seperti usia (Wyatt, 2005), gender (Stokes, 2003), pengalaman menggunakan internet (Stokes, 2003), dan pengalaman pembelajaran jarak jauh (Arbaugh, 2004).

Di sisi lain, penelitian lain tidak menemukan signifikan hubungan antara kepuasan peserta didik dan karakteristik latar belakang mereka seperti jenis kelamin, usia, tingkat kelas, dan literasi komputer (Kitchen \& McDougball, 1998). Sementara Astin (1993) menegaskan faktor-faktor kepuasan pembelajaran seperti hubungan dengan fakultas dan administrator, pembimbing akademik, dan kehidupan sosial di kampus, dapat dikaitkan dengan kepuasan pembelajaran mahasiswa. Selain itu, Bean dan Bradley (1986) menyoroti faktor-faktor, seperti integrasi akademik, kecocokan kelembagaan, kualitas dan kegunaan pendidikan, kehidupan sosial, dan kesulitan dengan kurikulum, ketika memprediksi kepuasan peserta didik.

Dalam perspektif psikologis dinyatakan bahwa setiap individu itu unik. Ini berarti bahwa meskipun setiap orang memiliki perasaan, dapat mengembangkan minat mereka, memiliki kemampuan untuk berpikir, tetapi setiap orang berbeda dari orang lain bagaimana merasakan, bagaimana mengembangkan pikiran mereka, bagaimana menentukan perkembangan minat pribadi. Hal ini berkaitan dengan kenyataan bahwa cara seseorang memproses dan bereaksi terhadap berbagai kebutuhan yang berasal dari luar dirinya sendiri memang berbeda untuk setiap orang.

Gaya belajar adalah suatu strategi yang menerangkan bagaimana individu belajar atau cara yang diambil oleh setiap orang untuk berkonsentrasi pada proses, dan menguasai informasi yang sulit dan baru melalui berbagai persepsi. Gaya adalah unik untuk setiap orang, dan berfungsi untuk membedakan antara individu yang satu dengan individu yang lain. Dengan demikian, umumnya gaya belajar diasumsikan merujuk pada kepribadian, kepercayaan, pilihan, dan perilaku yang digunakan oleh individu untuk membantu pembelajaran mereka dalam situasi terkondisi.

Menurut Montgomery dan Groat (1998), ada beberapa alasan mengapa gaya belajar perlu dipertimbangkan dalam proses pengajaran, yaitu, membuat proses belajar mengajar menjadi dialogis, memahami peserta didik lebih berbeda dengan menyesuaikan basis pengetahuan peserta didik, kesesuaian tugas, bidang, dan karierkarier yang sudah mereka miliki juga sesuai dengan kepribadian, bakat, dan membuat proses pembelajaran lebih bermanfaat sesuai dengan apa yang peserta didik miliki. 
Menurut Montgomery dan Groat (1998), ada beberapa alasan kenapa gaya belajar perlu di perhatikan dalam proses pengajaran, yaitu, membuat proses belajar mengajar menjadi dialogis, memahami mahasiswa lebih berbeda dengan menyesuaikan dasar pengetahuan pelajar, kesesuain tugas, area-area pokok, dan karier-karier yang telah mereka miliki juga kesesuaian fungsi kepribadian, bakat, serta membuat proses pengajaran lebih banyak memberi penghargaan pada apa yang telah dimiliki mahasiswa.

Merriam dan Caffarella (1991) mendefinisikan gaya belajar yang populer di dalam pendidikan orang dewasa, yaitu: "karakteristik individu menganai cara dalam memproses informasi, merasa, dan bertindak di dalam situasi-situasi belajar". Menurut James dan Gardner yang dikutip Ghufron dan Risnawita (2012; 2013) berpendapat bahwa gaya belajar adalah cara yang berbeda-beda yang dianggap peserta didik paling efektif dan efisien dalam memproses, menyimpan dan memanggil kembali apa yang telah mereka pelajari. Sementara Keefe yang dikutip Ghufron dan Risnawita, (2012; 2013) mengenai gaya belajar adalah "faktor-faktor kognitif, afektif, dan fisiologis yang menyajikan beberapa indikator yang relatif stabil tentang bagaimana para peserta didik merasa, berhubungan dengan lainnya dan bereaksi terhadap lingkungan belajar".

Menurut Kolb yang dikutip oleh Riding dan Rayner (2002) bahwa gaya belajar adalah metode yang dimiliki oleh individu guna mendapatkan informasi, oleh karenanya, gaya belajar juga adalah bagian integral dari pembelajaran aktif. Kolb (1984) bahkan menegaskan gaya belajar yang berbeda yang dipilih menunjukkan cara tercepat dan terbaik untuk setiap individu dalam upaya memahami informasi dari luar. Sejalan dengan Kolb, beberapa penulis menggambarkan gaya belajar sebagai pola stabil yang dimiliki oleh individu, dalam menerima, menyimpan, mengatur, dan memproses informasi (Gunawan, 2006; Susilo, 2006; Ghufron dan Risnawita, 2013).

Definisi yang dijelaskan di atas dapat dipahami bahwa definisi gaya belajar sangat beragam, memiliki perspektif berbeda tentang alat ukur untuk gaya belajar. Dua istilah yang sering digunakan secara bergantian adalah gaya kognitif dan gaya belajar. Gaya kognitif terkait dengan "bentuk" aktivitas kognitif (yaitu, berpikir, perasaan, pemecahan masalah, dan lain-lain), dan bukan isinya. Inilah yang dimaksudkan untuk mewujudkan "dimensi penguat" keyakinan, perbedaan kutub alami dan stabil dari waktu ke waktu. Gaya belajar, di sisi lain, dapat dilihat secara lebih luas yang menggabungkan aspek kognitif bersama dengan gaya afektif dan fisiologis. 
Menurut Ghufron dan Risnawita (2013), perkembangan teori gaya belajar sangatlah cepat. Sampai sekarang ini terdapat beberapa teori mengenai gaya belajar dan salah satu teori gaya belajar tersebut adalah model kepribadian berupa gaya belajar tergantung (field dependence learning style) dan gaya belajar bebas (Independence learning style) (Witkin, Oltman, Raskin, \& Karp, 1971). Individu disebut sebagai pemilik gaya belajar tergantung adalah ketika ia mempersepsikan diri berada di bawah pengaruh lingkungan. Sebaliknya, individu dianggap mempunyai gaya belajar bebas ketika individu mempersepsikan bahwa sebagian besar perilaku tidak dipengaruhi oleh lingkungan.

Gaya belajar mengalami perkembangan yang sangat cepat sampai sekarang. Salah satu dari teori gaya belajar ini adalah model yang sesuai dengan gaya belajar field dependence learning style yang selanjutnya disebut gaya belajar tergantung dalam tulisan ini dan gaya belajar independence learning style atau selanjutnya disebut gaya belajar bebas (Witkin, Oltman, Raskin, \& Karp, 1971). Individu yang disebut sebagai pemilik gaya belajar bergantung memerlukan kesesuaian dengan lingkungan yang sangat tinggi sehingga terkadang menyulitkan diri mereka sendiri di bawah pengaruh lingkungan. Sebaliknya, individu dengan gaya belajar bebas mempunyai kemudahankemudahan dalam belajar dengan menyesuaikan dengan lingkungan, dan individu merasa sebagian besar tidak terkait dengan lingkungan.

Luk (1998) berpendapat bahwa individu dengan gaya belajar tergantung ialah individu yang memiliki keterkaitan dengan keterampilan sosial, sikap, persepsi, kualitas, perasaan dan sangat dipengaruhi oleh latar belakang fisik dan sosial. Oleh karenanya, individu dengan gaya belajar ini bergantung pada orang lain untuk informasi, bimbingan dan pemeliharaan sikap. Karakteristiknya adalah memiliki sifat terbuka (ekstrovert), membutuhkan stimulasi dan motivasi dari orang-orang di sekitar dan orang-orang penting dalam kehidupan mereka (Witkin et al., 1971; Ghufron dan Risnawita, 2013).

Sebaliknya, individu dengan gaya belajar bebas mempunyai kecenderungan lebih analitis, logis, dan lebih mampu merestrukturisasi dan menggambarkan aspek masalah. Akibatnya, individu dengan gaya belajar bebas tidak banyak dipengaruhi oleh figur otoritas, masalah sosial dan eksternal di luar diri mereka sendiri dan dibimbing oleh kebutuhan mereka sendiri. Karakteristiknya adalah memiliki sifat tertutup 
(introvert), mempunyai kecenderungan melakukan kegiatan secara maksimal dengan keinginan sendiri (misalnya, belajar sendiri) bahkan tanpa motivasi atau penguatan orang-orang di sekitar, bekerja secara teratur dan fokus serta menyukai kompetisi. Dibandingkan dengan kepribadian tergantung, individu tipe bebas memiliki orientasi sosial yang lebih rendah, (Witkin et al, 1971; Ghufron dan Risnawita, 2013). Witkin et al juga mengatakan bahwa individu dengan gaya belajar bebas menyukai pembelajaran yang memiliki tujuan yang jelas dan memberikan lebih banyak kebebasan belajar untuk diri sendiri.

Gaya belajar peserta didik membentuk pengalaman mereka baik secara tradisional tatap muka maupun kursus dan kursus online (Graf, Liu, \& Kinshuk, 2010). Gaya belajar menyediakan informasi tentang bagaimana peserta didik mendekati pengalaman belajar serta bagaimana mereka menerima dan memproses informasi, dan gaya belajar menunjukkan perbedaan dalam preferensi belajar peserta didik. Oleh karena itu, gaya belajar dapat mendorong cara-cara pengajaran yang dapat dirancang dengan baik untuk mendukung pembelajaran peserta didik (Akdemir \& Koszalka, 2008). Gaya belajar dapat menjadi panduan penting bagi instruktur dalam perencanaan dan penyampaian instruksi online, yang mengarah pada pengembangan lingkungan belajar yang berkualitas tinggi serta memenuhi kebutuhan beragam peserta didfik dalam pembelajaran secara online.

Clariana \& Smith (1988) menemukan bahwa gaya belajar peserta didik akan menentukan strategi pembelajaran. Peserta didik dengan gaya belajar yang berbeda memiliki cara belajar yang berbeda. Biasanya, individu yang mempunyai gaya belajar yang berbeda akan memiliki keahlian yang berbeda untuk dikembangkan dalam setiap jenis bidang pembelajaran dengan alasan sifat belajar yang berbeda. Bostrom, Olfman dan Sein (1990) mengadopsi teori belajar pengalaman (Kolb, 2014) telah menguji gaya belajar individu dan dalam pembelajaran. Hasil menunjukkan bahwa peserta pelatihan yang memiliki gaya belajar yang berbeda akan memiliki efektivitas belajar yang berbeda.

Pengaruh gaya belajar pada hasil belajar juga telah diteliti oleh Sein dan Robey (1991) yang menemukan bahwa gaya belajar Converger berkinerja lebih baik daripada individu dengan gaya belajar yang lain dalam metode pelatihan komputer. Gunawardena dan Boverie (1993) meneliti gaya belajar dalam pembelajaran secara e-learning yang 
dimediasi komputer. Hasilnya menunjukkan bahwa gaya belajar peserta didik berbedabeda serta dikuti tingkat kepuasan yang berbeda pula. Secara khusus, gaya belajar akomodator adalah yang paling puas. Sementara gaya belajar diverger adalah yang paling tidak puas dengan kegiatan kelas e-learning.

Chou dan Wang (2000) menguji efektivitas e-learning di antara siswa sekolah menengah dengan gaya belajar yang berbeda. Hasil penelitiannya menunjukkan bahwa gaya akomodator dan konvergen menunjukkan hasil efektivitas pembelajaran elearning yang lebih tinggi. Wang, Wang, Wang dan Huang (2006) meneliti hubungan antara gaya belajar dan prestasi siswa dalam lingkungan belajar berbasis web. Hasil penelitian mengungkapkan bahwa peserta didik dengan gaya belajar diverger berkinerja paling baik, diikuti oleh gaya belajar assimilator, accommodator, dan Converger.

Cheng, Chiu, Wu dan Tsaih (2017) meneliti pengaruh gaya belajar (akomodator, diverger, converger dan assimilator) terhadap kepuasan pengguna pada sistem pembelajaran berbasis web dan efektivitas pembelajarannya. Di antara hasil penelitian ini menunjukkan bahwa kepuasan sistem pembelajaran berbasis web memiliki pengaruh signifikan terhadap kinerja pembelajaran peserta didik sementara gaya belajar yang berbeda pada peserta didik tidak memiliki pengaruh yang signifikan terhadap kepuasan menggunakan sistem pembelajaran berbasis web.

Penelitian untuk mengungkap kepuasan pembelajaran secara online memang telah banyak dilakukan, seperti dari faktor media yang digunakan, administrasi pendukung, kemampuan individu dalam menggunkan teknologi dan faktor karakteristik peserta didik seperti efikasi diri, kehadiran sosial, interaksi serta gaya belajar model Kolb. Namun demikian, masih jarang penelitian kepuasan pembelajaran secara online ditinjau dari faktor gaya belajar tergantung dan gaya belajar bebas. Dengan demikian, tujuan penelitian ini adalah untuk menguji adakah pengaruh gaya belajar terhadap kepuasan pembelajarn secara online mahasiswa.

Penelitian ini dilakukan secara kuantitatif. Tehnik pengambilan sampel dalam penelitian ini adalah purposive sampling, yaitu mengambil sampel dengan tujuan tertentu yang dalam penelitian ini pada sampel mahasiswa IAIN Kudus yang mengikuti pembelajaran secara online. Jumlah sampel di dapatkan berjumlah 69 mahasiswa.

Teknik pengumpulan data yang digunakan dalam penelitian ini adalah kuesioner dalam bentuk skala. Ada tiga jenis skala yang digunakan dalam proses pengumpulan 
data, yaitu skala pembelajaran secara online, gaya belajar tergantung, gaya belajar bebas dan skala kepuasan pembelajarn secara online.

Variabel kepuasan belajar online ini diungkap dengan menggunakan skala kepuasan belajar yang di modifikasi berdasarkan survei kepuasan mahasiswa dikembangkan Flowers et al., (2004), dengan indikator efektivitas pembelajaran yang dirasakan, efektivitas instruktur, dan efektifitas secara keseluruhan. Intrumen ini mempunyai 24 item.

Gaya belajar tergantung dalam penelitian ini adalah gaya atau pola tertentu yang stabil ketika individu menerima, berinteraksi, menyerap, menyimpan, mengatur, dan memproses informasi di mana individu memiliki kecenderungan untuk melihat berbagai hal secara global, membuat perbedaan konseptual yang luas, menunjukkan orientasi sosial dan menetapkan tujuan serta penguatan. Variabel ini dinyatakan dengan menggunakan skala gaya belajar tergantung pada sebagaimana karakteristik yang diusulkan oleh Witkin et al (Ghufron dan Risnawita, 2013). Sementara individu dengan gaya belajar bebas adalah individu yang memiliki kecenderungan untuk melihat hal-hal secara analitis, membuat konsep yang berbeda, menunjukkan orientasi impersonal dan memiliki tujuan yang dirancang sendiri. Variabel ini diungkap dengan menggunakan skala gaya belajar bebas dengan komponen serta karakteristik yang dikemukakan oleh (Ghufron dan Risnawita, 2013).

Hasil perhitungan reliabilitas skala gaya belajar tergantung mendapatkan reliabilitas 0,71 , sementara pada gaya belajar bebas mendapatkan reliabilitas 0,74 . Sementara hasil reliabilitas kepuasan pembelajarn secara online sebesar 0,78. Dengan demikian, hasil reliabilitas variabel secara keseluruhan dalam penelitian ini mendapatkan > 0,60 yang dapat dinyatakan bahwa seluruh variabel yang digunakan telah memenuhi syarat reliabilitas.

Teknik analisis data yang digunakan dalam penelitian ini adalah dengan menggunakan analisis regresi. 


\section{B. Pembahasan}

Sebelum dilakukan analisis model, akan dipaparkan terlebih dahulu data deskriptif penelitian untuk tiap variabel. Deskripsi statistik data penelitian diringkas pada table 1 berikut:

Tabel 1. Deskripsi data penelitian

\begin{tabular}{llllll}
\hline Variabel & $\mathrm{N}$ & Minimum & Maximum & Mean & $\begin{array}{l}\text { Std. } \\
\text { Deviation }\end{array}$ \\
\hline $\begin{array}{l}\text { Gaya Belajar } \\
\text { Bebas }\end{array}$ & 69 & 22 & 69 & 42,61 & 9,563 \\
$\begin{array}{l}\text { Gaya Belajar } \\
\text { Tergantung }\end{array}$ & 69 & 13 & 47 & 31,70 & 7,240 \\
$\begin{array}{l}\text { Kepuasan } \\
\text { Pembelajaran }\end{array}$ & 69 & 13 & 51 & 30,23 & 8,954 \\
Online & & & & & \\
\hline
\end{tabular}

Berdasarkan tabel 1 di atas diketahui untuk variabel gaya belajar bebas mendapatkan skor empirik sebesar 42.61, dengan nilai standar deviasi sebesar 9.563, variabel gaya belajar tergantung mendapatkan skor empiriknya sebesar 31.70, dengan standar deviasi 7.240, dan variabel kepuasan pembelajaran secara online mendapatkan skor rerata empiriknya sebesar 30.23, dengan nilai standar deviasi sebesar 8.954.

Korelasi Pearson digunakan untuk menguji hubungan antar variabel penelitian yang meliputi hubungan variabel gaya belajar bebas, gaya belajar tergantung dan kepuasan pembelajaran secara online seperti yang ditunjukkan pada Tabel 2.

Tabel 2. Hasil nilai korelasi antar variabel

\begin{tabular}{llll}
\hline Variabel & Gaya Belajar Bebas & $\begin{array}{l}\text { Gaya Belajar } \\
\text { Tergantung }\end{array}$ & $\begin{array}{l}\text { Kepuasan } \\
\text { Pembelajaran } \\
\text { Online }\end{array}$ \\
\hline 1 & 0,009 & $0,472^{* *}$ \\
& 0,940 & 0,000 \\
0,009 & 1 & $-0,519^{* *}$ \\
0,940 & & 0,000 \\
$0,472^{* *}$ & $-0,519^{* *}$ & 1 \\
0,000 & 0,000 &
\end{tabular}

Note: $N=69, * * p<0.01, * p<0.05$ 
Berdasarkan tabel di atas menunjukkan bahwa variabel gaya belajar bebas mempunyai korelasi positif dengan kepuasan pembelajarn secara online sebesar $0.472, p$ $<0.00$. Variabel gaya belajar tergantung mempunyai korelasi negatif dengan kepuasan pembelajarn secara online sebesar $-0.519 \mathrm{p}<0.00$. Dengan demikian, seluruh variabel gaya belajar bebas dan gaya belajar tergantung mempunyai korelasi yang sangat signifikan dengan kepiuasan pembelajarn secara online. Namun demikian, untuk melihatnya besarnya pengaruh masing-masing variabel dapat dilihat tabel 3 berikut.

Tabel 3. Coefficients Variabel.

\begin{tabular}{|c|c|c|c|c|c|}
\hline & $\begin{array}{l}\text { Unstandardized } \\
\text { Coefficients }\end{array}$ & & $\begin{array}{c}\text { Standardized } \\
\text { Coefficients }\end{array}$ & $\mathrm{t}$ & Sig. \\
\hline & $\mathrm{B}$ & Std. Error & Beta & & \\
\hline (Constant) & 31,731 & 4,926 & & 6,442 & 0,000 \\
\hline $\begin{array}{l}\text { Gaya Belajar } \\
\text { Bebas }\end{array}$ & 0,446 & 0,082 & 0,477 & 5,454 & 0,000 \\
\hline $\begin{array}{l}\text { Gaya Belajar } \\
\text { Tergantung }\end{array}$ & $-0,647$ & 0,108 & $-0,523$ & $-5,988$ & 0,000 \\
\hline
\end{tabular}

Dependent Variable: Kepuasan pembelajaran secara online

Berdasarkan tabel di atas dapat dilihat besarnya nilai signifikansi gaya belajar bebas sebesar $0.000<0.05$ berarti terdapat pengaruh secara positif (nilai constan) 0.446 terhadap kepuasan pembelajarn secara online. Sementara gaya belajar tergantung juga berpengaruh, namun secara negatif terhadap kepuasan pembelajarn secara online terlihat dari nilai constan sebesar -0.647 dengan nilai signifikansi $0.000<0.05$. Adapun besarnya koeffisien determinasi variabel dapat dilihat pada tabel 4 berikut.

Tabel 4. Koefisien determinasi variabel.

\begin{tabular}{llrrr}
\hline Model & $\mathrm{R}$ & R Square & Adjusted R Square & $\begin{array}{l}\text { Std. Error of } \\
\text { the Estimate }\end{array}$ \\
\hline 1 & $0,704^{\mathrm{a}}$ & 0,496 & 0,481 & 6,451 \\
\hline
\end{tabular}

a. Predictors: (Constant), Gaya Belajar Tergantung dan gaya Belajar Bebas

b. Dependent Variable: Kepuasan Pembelajaran secara Online

Berdasarkan tabel 4 di atas dapat terlihat bahwa koefesien determinasi kepuasan pembelajarn secara online sebesar $\left(\mathrm{R}^{2}\right)=0.496$, yang bermakna bahwa 49 persen kepuasan pembelajaran secara online dapat dijelaskan atau diprediksi melalui variabel 
gaya belajar, baik gaya belajar bebas maupun gaya belajar tergantung. Sementara 61 persen di pengaruhi oleh variabel diluar penelitian ini.

Berdasarkan uraian di atas, dapat disimpulkan bahwa hipotesis pertama menyatakan bahwa gaya belajar bebas berpengaruh terhadap kepuasan pembelajaran secara online dapat diterima. Sementara itu, hipotesis kedua menyatakan bahwa gaya belajar tergantung berpengaruh terhadap kepuasan pembelajarn secara online juga dapat diterima.

Penggunaan teknologi informasi dan komunikasi memiliki korelasi yang kuat dengan preferensi gaya belajar peserta didik dan penggunaan teknologi terbaru (Cheng, Chiu, Wu dan Tsaih, 2017) dan pendekatan belajar (Ghufron, 2020). Tidak mudah untuk mengubah gaya belajar peserta didik; namun penggunaan teknologi baru yang sesuai dapat membantu dalam menyampaikan materi dengan cara yang dapat dipelajari peserta didik dengan sukses dan mendapatkan kepuasan.

Menurut Bolliger \& Halupa (2012), kepuasan adalah masalah yang sangat signifikan dalam pelaksanaan proses pembelajaran secara online dan merupakan ukuran kualitas dan efektivitas pengajaran dan pembelajaran. Menurut Kelsey, Lindner, \& Dooley (2002), dengan diketahui kepuasan pembelajaran mahasiswa secara online dapat membantu para pendidik dan pengembang pendidikan secara online dalam meningkatkan efektivitas pembelajaran, dapat digunakan sebagai referensi untuk perancang kurikulum pembelajarn secara online. Juga, ini dapat membantu para pengajar untuk memiliki pemahaman yang lebih baik tentang situasi belajar mengajar.

Hasil analisis penelitian ini diketahui bahwa gaya belajar tergantung berpengaruh signifikan secara negatif terhadap kepuasan pembelajaran secara online. Hasil tersebut bisa dipahami karena individu dengan gaya belajar tergantung memerlukan penyesuaian pada lingkungan, terutama pada lingkungan yang baru (Ghufron dan Risnawita, 2012; 2013) yang implikasinya dalam penggunaan media pembelajaran baru akan memerlukan penyesuaian diri yang lebih tinggi.

Berdasarkan hasil analisis penelitian ini juga diketahui bahwa, gaya belajar berpengaruh positif signifikan terhadap kepuasan belajar online. Hasil ini dapat dipahami karena, individu dengan gaya belajar bebas menganggap bahwa sebagian besar dari apa yang dilakukan tidak dipengaruhi oleh lingkungan, individu memiliki kemampuan untuk melakukan suatu kegiatan secara maksimal oleh keinginan mereka 
sendiri (misalnya, belajar mandiri, dengan tempat dan media bervariasi) bahkan tanpa motivasi atau penguatan orang di sekitar, bekerja secara teratur dan fokus serta menyukai persaingan. (Witkin et al., 1971; Ghufron dan Risnawita, 2012; 2013). Individu dengan gaya belajar bebas memiliki kecenderungan untuk belajar dengan tujuan yang jelas dan memberikan lebih banyak kebebasan untuk belajar kepada diri mereka sendiri di mana pun mereka berada (Witkin et al., 1971; Ghufron dan Risnawita, 2012; 2013), dan pada akhirnya individu akan dengan mudah menyesuaikan diri dengan pembelajaran yang berbeda. media, khususnya pembelajaran online.

Hasil penelitian ini sesuai dengan penelitian sebelumnya (seperti Clariana dan Smith, 1988; Bostrom, Olfman dan Sein, 1990; Sein dan Robey, 1991; Gunawardena dan Boverie, 1993) menunjukkan bahwa kepuasan pembelajaran secara online dapat dipengaruhi gaya belajar yang dimiliki oleh mahasiswa. Sementara berdasarkan hasil penelitian ini gaya belajar bebas mendapatkan kepuasan pembelajaran secara online yang lebih tinggi dibandingkan gaya belajar tergantung.

\section{Simpulan}

Hasil penelitian ini dapat disimpulkan bahwa gaya belajar bebas dan gaya belajar tergantung berpengaruh terhadap kepuasan pembelajarn secara online. Gaya belajar bebas mempunyai pengaruh yang positif terhadap kepuasan pembelajarn secara online. Artinya, semakin tinggi mahasiswa mempunyai gaya belajar bebas, maka semakin tinggi pula kepuasan pembelajar secara onlinenya. Berbeda arah hubungan dengan gaya belajar tergantung yang mempunyai pengaruh yang negatif terhadap kepuasan pembelajarn secara online. Artinya, semakin tinggi gaya belajar tergantung yang dimiliki mahasiswa, semakin rendah kepuasan pembelajaran secara online.

Hasil penelitian ini telah membuktikan bahwa kepuasan pembelajaran secara online dipengaruhi karakteristik internal yang dimiliki oleh mahasiswa yaitu gaya belajar. Oleh karenanya, para peneliti masa depan, penting untuk melakukan penelitian yang melibatkan faktor eksternal yang mempengaruhi kepuasan pembelajaran secara online. Dengan melibatkan faktor atau variabel eksternal, diharapkan bahwa pemahaman tentang faktor-faktor yang mempengaruhi kepuasan pembelajaran secara online akan menjadi lebih komprehensif. Untuk pendidik, sangat penting dalam 
memberikan vareasi dalam proses pembelajaran baik secara tatap muka ataupun secara online. Demikian ini dilakukan untuk mengakomodir perbedaan gaya belajar yang dimiliki oleh mahasiswa. Mengingat kepuasan pembelajaran secara online lebih tinggi didapat pada mahasiswa dengan gaya belajar bebas. 


\section{Daftar Pustaka}

Akdemir, O. \& Koszalka, T.A. (2008). Investigating the relationships among instructional strategies and learning styles in online environments. Computers \& Education, 50(4), 1451-1461. Elsevier Ltd. Retrieved May 29, 2020 from https://www. learntechlib.org/p/67213/.

Allen, M., Bourhis, J., Burrell, N., \& Mabry, E. (2002). Comparing student satisfaction with distance education to traditional classrooms in higher education: A metaanalysis. The American Journal of Distance Education, 16(2), 83-97.

Arbaugh, J. B. (2004). Learning to Learn Online: A study of perceptual changes between multiple online course experiences. The Internet and Higher Education, 7(3), 169-182.

Astin, A. W. (1993). What matters in college? Four critical years revisited. San Francisco, CA: Jossey-Bass.

Battalio, J. (2007). Interaction online: A reevaluation. Quarterly Review of Distance Education, 8(4), 339-352.

Bean, J. P., \& Bradley, R. K. (1986). Untangling the satisfaction-performance relationship for college students. Journal of Higher Education, 57(4), 393412. https://doi.org/10.2307/1980994

Biner, P. M., Bink, M. L., Huffman, M. L., \& Dean, R. S. (1997). The impact of remote-site group size on student satisfaction and relative performance in interactive telecourses. The American Journal of Distance Education, 11(1).

Bolliger, D. U., \& Halupa, C. (2012). Student perceptions of satisfaction and anxiety in an online doctoral program. Distance Education, 33(1), 81-98. doi.org/10.1080/01587919.2012.667961

Bolliger, D. U., \& Halupa, C. (2018). Online student perceptions of engagement, transactional distance, and outcomes. Distance Education, 39(3), 299-316. doi.org/10.1080/01587919. 2018.1476845

Bostrom, R.P., Olfman, L. and Sein, M.K. (1990), The importance of learning style in end-user training, MIS Quarterly, 14 (1).

Cheng, F.-F., Chiu, C.-C., Wu, C.-S. \& Tsaih, D.-C. (2017). The influence of learning style on satisfaction and learning effectiveness in the asynchronous webbased learning system. Library Hi Tech, 35 (4), 473-489. https://doi.org/10.1108/LHT-12-2016-0151

Chou, H.-W. \& Wang, T.-B. (2000), The influence of learning style and training method on self-efficacy and learning performance in WWW homepage design training. International Journal of Information Management, 20 (6), 455472.

Clariana, R. B. \& Smith, L., (1988). Learning Style Shifts in Computer-assisted Instructional Settings. London: C. V. Mosby Company.

Dennen, V. P., Aubteen Darabi, A., \& Smith, L. J. (2007). Instructor-Learner Interaction in Online Courses: The relative perceived importance of 
particular instructor actions on performance and satisfaction. Distance Education, 28(1), 65-79. doi:10.1080/01587910701305319

Diwan, P. (2017). Is Education 4.0 an imperative for success of 4th Industrial Revolution? Accessed from https://medium.com/@ pdiwan/is-education-4-0an-im-perative- for-success-of-4th-ind ustrial-revolu-tion-50c31451e8a4

Dziuban, C., Graham, C. R., Moskal, P. D., Norberg, A., \& Sicilia, N. (2018). Blended learning: the new normal and emerging technologies. International Journal of Educational Technology in Higher Education, 15(1). doi:10.1186/s41239-017-0087-5

Flowers, C., Jordan, L., Algozzine, B., Spooner, F., \& Fisher, A. (2001). Compari-son of student rating of instruction in distance education and traditional courses. Proceedings of the Society for Information Technology and Teacher EducationInternational Conference, 1,2314-2319.

Ghufron, M., N \& Risnawita, R. (2013). Review of Learning Styles on Student with Self-Regulated Learning. Anima, Indonesian Psychological Journal, 29(1).

Ghufron, M., N. (2020). Epistemological Beliefs and Mediating Role of Learning Approaches on Social Attitudes of SHS Students. Universal Journal of Educational Research 8(1), 202-211, $2020 . \quad$ DOI: 10.13189/ujer.2020.080125

Ghufron, M.N. \& Risnawita, R., (2012) Gaya Belajar; Kajian Teoretik. Yogyakarta; Pustaka Pelajar

Graf, S., Liu, T.C. \& Kinshuk. (2010). Analysis of Learners' Navigational Behaviour and Their Learning Styles in an Online Course. Journal of Computer Assisted Learning, 26(2), 116-131. Wiley. Retrieved May 8, 2020 from https://www.learntechlib.org/p/108289/.

Gunawan, W. A. (2006). Genius Learning Strategy. Jakarta: PT. Gramedia.

Gunawardena, C. \& Boverie, P. (1993), Impact of learning styles on instructional design for distance education. World Conference of the International Council of Distance Education, Bangkok, November 8-13.

Johnson, S. D., Aragon, S. R., Shaik, N., \& Palma-Rivas, N. (2000). Comparative analysis of learner satisfaction and learning outomes in online and face-toface learning environments. Journal of Interactive Learning Research, 11(1), 29-49.

Keller, J. M. (1983). Motivational design of instruction. In C. Reigeluth (Ed.), Instructional design theories and models: An overview of their current status (pp. 386-434). Hillsdale, NJ: Erlbaum.

Kelsey, K. D., Lindner, J. R., \& Dooley, K. E. (2002). Agricultural education at a distance: Let's hear from the students. Journal of Agricultural Education, 43(4).

Kitchen, D. \& McDougall, D.(1998). Collaborative Learning on the Internet. Journal of Educational Technology Systems, 27(3), 245. 
Kolb, D. A. (1984). Experiential Learning: Experience as The Source of Learning and Development. New Jersey : Prentice-Hall.

Kolb, D.A. (2014), Experiential Learning: Experience as the Source of Learning and Development, FT press, Upper Saddle River, NJ.

Liaw, S.-S. (2008). Investigating students' perceived satisfaction, behavioral intention, and effectiveness of e-learning: A case study of the Blackboard system. Computers \& Education, 51(2), 864-873. doi:10.1016/j.compedu.

Luk, S. (1998). The relationship between cognitive style and academic achievement. British Journal of Educational Technology, 29, 137-147.

McGivney, V. (2004). Understanding persistence in adult learning. Open Learning, $19(1)$.

Merriam, S. B., \& Caffarella, R. S. (1991). Learning in Adulthood. San Francisco, CA: Jossey-Bass.

Montgomery, S.,M. \& Groat L., N. (1998) Student Learning Styles and their implications for teaching. CRLT Occasional Paper No 10. Michigan: The Center for Research on Learning and Teaching The University of Michigan.

Phipps, R., \& Merisotis, J. (1999). What's the Difference? A Review of Contemporary Research on the Effectiveness of Distance Learning in Higher Education. Washington DC: Institute for Higher Education Policy.

Pike, G. R. (1993). The relationship between perceived learning and satisfaction with college: An alternative view. Research in Higher Education, 34(1).

Reinhart, J. \& Schneider, P. (2001). Student Satisfaction, Self-Efficacy, and the Perception of the Two-Way Audio/Video Distance Learning Environment: A Preliminary Examination. Quarterly Review of Distance Education, 2(4), 357. Retrieved May 9, 2020 from https://www.learntechlib.org/p/92806/.

Riding, R. \& Rainer, S. (2002). Cognitive Style \& Learning strategies understanding style differences in learning and behaviour. London: David Fulton Publishers.

Sahin, I., \& Shelley, M. (2008). Considering students' perceptions: The distance education student satisfaction model. Journal of Educational Technology \& Society, 11(3).

Sein, M.K. \& Robey, D. (1991), Learning style and the efficacy of computer training methods, Perceptual and Motor Skills, 72 (1), pp.

Shelton, B. E., Hung, J. L., \& Lowenthal, P. R. (2017). Predicting student success by modeling student interaction in asynchronous online courses. Distance Education, 38(1). doi.org/10. 1080/01587919.2017.1299562

Stokes, S. P. (2003). Temperament, learning styles, and demographic predictors of college student satisfaction in a digital learning environment. Paper presented at the annual meeting of the Mid-South Educational Research Association, Biloxi, MS. Retrieved from https://files.eric.ed.gov/fulltext/ED482454.pdf 
Susilo, M. J. (2006). Gaya Belajar Menjadikan Makin Pintar. Yogyakarta: Penerbit Pinus.

Wang, K.H., Wang, T.H., Wang, W.L. and Huang, S.C. (2006). Learning styles and formative assessment strategy: enhancing student achievement in web-based learning. Journal of Computer Assisted Learning, 22(3), pp.

Weidlich, J., \& Bastiaens, T. J. (2018). Technology Matters - The Impact of Transactional Distance on Satisfaction in Online Distance Learning. The International Review of Research in Open and Distributed Learning, 19(3). https://doi.org/10.19173/irrodl.v19i3.3417

Wickersham, L. E., \& McGee, P. (2008). Perceptions of satisfaction and deeper learning in an online course. Quarterly Review of Distance Education, 9.

Witkin, H. A., Oltman, P. K., Raskin, E., \& Karp, S. A. (1971). The effect of training and of structural aids on performance in three tests of space orientation. (Report No. 80). Washington, D.C.: Civil Aeronautics Administration, Division of Research.

Wyatt, G. (2005). Satisfaction, academic rigor and interaction: Perceptions of online instruction. Education, 125(3).

Yang, D., Baldwin, S., \& Snelson, C. (2017). Persistence factors revealed: Students' reflections on completing a fully online program. Distance Education, 38(1). doi.org/10.1080/ 01587919.2017.1299561 